\title{
DISFUNGSI SEKSUAL BERHUBUNGAN DENGAN \\ KEHARMONISAN RUMAH TANGGA PADA LANSIA
}

\author{
SEXUAL DYSFUNCTION IS ASSOCIATED WITH \\ MARITAL HARMONY IN ELDERLY
}

\author{
Oleh : \\ Afrina Zulaikha* \\ Marlina S. Mahajudin **
}

"Dokter umum, peserta PPDS 1 Psikiatri Departemen/SMF Ilmu Kedokteran Jiwa FK Universitas Airlangga/RSUD Dr. Soetomo Surabaya. Alamat korespondensi Jl. Gubeng Airlangga 3/48, Surabaya, Jawa Timur. Email: dr.afrinazulaikha@gmail.com. HP. 081361740500

** Dokter Spesialis Kedokteran Jiwa/Psikiater, Guru Besar Departemen/SMF Ilmu Kedokteran Jiwa FK Universitas Airlangga/RSUD Dr. Soetomo Surabaya. 


\begin{abstract}
ABSTRAK
Peningkatan usia harapan hidup menyebabkan peningkatan jumlah lansia dengan segala permasalahannya. Perubahan bentuk tubuh, penurunan fungsi organ, gejala-gejala menopause, penyakit degeneratif dan lainnya menimbulkan stress tersendiri dan memerlukan adaptasi dan penanganan yang baik. Salah satu masalah utama yang dihadapi oleh pasangan lansia adalah disfungsi seksual akibat terjadinya perubahan dan penurunan fungsi organ seksual. Aktifitas seksual merupakan merupakan hal yang fundamental dalam membentuk kedekatan antara suami dan istri dan sangat erat kaitannya dengan kualitas dan stabilitas perkawinan. Berbagai perubahan yang dialami, disadari dan saling dimengerti diantara pasangan lansia dalam melewati fase-fase pernikahan akan menimbulkan suatu kepuasan yang holistik tidak hanya kepuasaan seksual. Namun hal ini juga dipengaruhi oleh latar belakang pendidikan dan kebudayaan seseorang. Kelekatan, intimasi, aktifitas seksual, dan komunikasi yang baik menciptakan kualitas pernikahan yang baik Disfungsi seksual pada lansia tidak mempengaruhi keharmonisan rumah tangga karena proses adaptasi yang baik, kemampuan pemecahan masalah, intimasi dan kelekatan serta komunikasi yang baik. Disamping itu pada lansia juga telah terjadi pergeseran dari cinta eros menjadi agape, sehingga cinta eros yang dipengaruhi oleh struktur biologispun tertutupi oleh cinta filia dan agape yang akhirnya meningkatkan ketiga cinta tersebut. Pasangan lansia yang memiliki kendala dalam hal seksualitas dapat meminta bantuan kepada tenaga kesehatan profesional. Penanganan yang bisa diberikan berupa konseling dan edukasi, farmakoterapi, terapi non famakologi seperti terapi perilaku kognitif, terapi pasangan dan terapi seksual yang melibatkan pasangannya.
\end{abstract}

\title{
Kata kunci : disfungsi seksal, lanjut usia, pernikahan
}

\begin{abstract}
An increase in life expectancy leads to an increase in the number of elderly people with all the problems. Changes in body shape, decreased organ function, menopausal symptoms, degenerative diseases can cause stress and require good adaptation and treatment. One of the main problems that faced by elderly is sexual dysfunction. Sexual activity is fundamental in establishing the closeness of husband and wife and is closely related to the quality and stability of marriage. Various changes make them realized and understood about each othersand lead to a holistic satisfaction not only sexual satisfaction. But it is also influenced by the educational background and one's culture. Attachment, intimacy, sexual activity, and good communication create good marriage quality. Sexual dysfunction in the elderly does not affect marriage harmony due to a good adaptation process, problem solving skills, intimacy and attachment and good communication. In addition to the elderly there has also been a shift from eros love to agape, so that eros love is influenced by the biological structure is covered by love of filia and agape which ultimately increase the three love. Elderly couples who have obstacles in sexuality can seek help to health professionals. Treatments that can be given in the form of counseling and education, pharmacotherapy, non-pharmacology therapy such as cognitive behavioral therapy, couple therapy and psychosexual therapy that involving both partners.
\end{abstract}

Keywords : sexual dysfunction, elderly, marriage 


\section{Pendahuluan}

Usia harapan hidup semakin meningkat setiap tahunnya. Rata-rata usia harapan hidup di seluruh dunia pada tahun 2015 adalah 71,4 tahun. Di Indonesia, usia harapan hidup meningkat dari 68,5 tahun pada tahun 2004 menjadi 72 tahun pada tahun 2015. Peningkatan ini diprediksi akan terus bertambah dan akan menghasilkan masalah-masalah terkait individu lanjut usia (lansia). Salah satu masalah yang mempengaruhi kualitas hidup lansia baik laki-laki maupun perempuan adalah masalah seksualitas (WHO 2015; Depkes, 2016; Ambler, Bieber dan Diamond, 2012).

Seksualitas merupakan bagian dari kedekatan fisik dan emosional yang ingin dirasakan oleh setiap laki-laki dan perempuan selama hidup mereka walaupun usia sudah bertambah. Bahkan lansia yang masih mampu secara fisik dan memiliki pasangan, serta melakukan aktivitas seksual akan mendapatkan kepuasan dari aktivitas tersebut dan dapat bertahan sampai usia 90 tahun-an (Mcnicoll, 2008; Ambler, Bieber dan Diamond, 2012).

Disfungsi seksual ditandai antara lain adanya gangguan pada siklus respon seksual atau nyeri yang terkait hubungan intim. Frank, Danerson, Rubenstein, dalam penelitiannya mengungkap lebih dari 50 persen pasangan melaporkan adanya disfungsi seksual. Sekitar 28\% laki-laki dan 39\% perempuan usia 40-80 tahun mengeluhkan setidaknya satu masalah fungsi seksual (Murphy, Hudson dan Cheung, 2015).

Aktivitas seksual merupakan hal yang fundamental dalam membentuk kedekatan antara suami dan istri. Kepuasan dari aktivitas seksual memiliki kaitan yang sangat erat dengan kualitas perkawinan dan stabilitas perkawinan pada pasangan yang awet perkawinannya. The Vitality for Life Committe, memperkirakan tahun 2010 hingga 2030 akan terjadi peningkatan individu dengan usia 65 tahun keatas sebesar $73 \%$ dan angka perceraian untuk kalangan usia pertengahan dan lansia pada saat itu mencapai 20\% (Melton, Hersen dan Hasselt, 1995; Hinchliff dan Gott, 2004; Yeh et al., 2006).

\section{Disfungsi Seksual pada Lansia}

\section{Disfungsi Seksual}

Disfungsi seksual menurut Diagnostic dan Statistical Manual of Mental Disorders fourth edition (DSM V) adalah sekelompok gangguan yang ditandai dengan adanya gangguan klinis yang signifikan dalam hal ketidakmampuan seseorang merespon secara seksual atau merasakan kenikmatan seksual.

\section{Lansia}

Lansia menurut World Health Organizaton (WHO) dan UU No. 13 tahun 1998 tentang Kesehatan pasal 1 ayat (2), (3), (4), menggolongkan seseorang sebagai lansia jika telah berumur di atas 60 tahun. 


\section{Prevalensi Disfungsi Seksual pada Lansia}

Masalah seksual yang paling sering dikeluhkan pada lansia pria adalah kesulitan mencapai dan mempertahankan ereksi (37\%), penurunan minat terhadap seksual (28\%), mencapai klimaks terlalu cepat (28\%), anxiety performance (27\%) dan tidak bisa mencapai klimaks (20\%). Sedangkan pada lansia perempuan yang paling sering dikeluhkan adalah berkurangnya minat terhadap aktivitas seksual (43\%), berkurangnya lubrikasi (39\%), tidak bisa mencapai klimaks (34\%) dan nyeri pada saat berhubungan seksual (17\%) (Lindau et al., 2007).

\section{Siklus Seksual Normal}

Siklus seksual normal terdiri dari empat fase, yaitu fase I hasrat (desire), ditandai dengan adanya fantasi seksual dan keinginan untuk berhubungan seksual. Hasrat dapat dicetuskan melalui proses biologis atau keinginan untuk menyatu atau terikat dengan pasangan; fase II excitement, muncul karena adanya stimulasi fisiologi, psikologis ataupun keduanya; fase III orgasme, tercapainya puncak kenikmatan seksual, pelepasan ketegangan seksual dan kontraksi ritmis otot perineal dan organ reproduktif yang terdapat di pelvis; fase IV resolusi, darah yang terbendung dalam corpora cavernosa penis kembali mengalir, mengakibatkan tubuh kembali kedalam keadaan istirahat (Sadock, Sadock dan Ruiz, 2017).

\section{Jenis-Jenis Disfungsi Seksual}

Jenis-jenis disfungsi seksual menurut DSM 5 terdiri dari: Male hypoactive sexual desire disorder, Female sexualinterest/arousal disorder, Erectile disorder, Female orgasmic disorder, Delayed ejaculation, Premature (early) ejaculation, Genito-pelvic pain/penetration disorder, Substance/medicationinduced sexual dysfunction, Other specified sexual dysfunction, dan Unspecified sexual dysfunction (Sadock, Sadock dan Ruiz, 2017).

\section{Faktor-faktor yang mempengaruhi disfungsi seksual pada lansia}

Usia

Perubahan anatomi terkait usia pada pria adalah penipisan rambut pubis, jaringan skrotum melemah, atrofi otot perineum, berkurangnya jaringan kolagen dan penambahan berat badan. (Phanjoo, 2000; Trudel, Turgeon dan Piché, 2010).

Perubahan fisiologis pada pria yaitu waktu yang dibutuhkan untuk mencapai ereksi menjadi lebih lama, membutuhkan stimulasi langsung dan adanya kesulitan untuk mempertahankan ereksi. Jumlah semen yang dihasilkan, kontraksi rektum, prostat dan penis juga lemah pada saat ejakulasi. Lansia lebih mampu mengontrol ejakulasi sehingga, memberikan kepuasan yang lebih dalam berhubungan seksual (Hillman, 2000; Gareri et al., 2014).

Perubahan pada perempuan setelah menopause yaitu, berkurangnya estrogen menimbulkan berbagai efek pada tubuh, seperti penipisan rambut pubis, vagina menjadi kering, mukosa menjadi tipis dan kering, rugae vagina menghilang, vaskularisasi, lemak subkutan serta kelenturan jaringan berkurang mengakibatkan labia mayor dan minor mengkerut dan menjadi tidak sensitif terhadap rangsangan taktil (Trudel, Turgeon dan Piché, 2010; Ambler, Bieber dan Diamond, 2012). 


\section{Hormon}

Perempuan yang mengalami menopause terjadi penurunan estrogen karena respon ovarium berkurang secara bertahap terhadap rangsangan gonadotropin-releasing hormon $(\mathrm{GnRH})$, folicle stimulating-releasing hormone (FSH) dan luteinizing hormone (LH) yang berasal dari kelenjar pituitari anterior. Hal ini menyebabkan folikel berhenti berkembang dan mengakibatkan berkurangnya pelepasan estrogen dan progesteron, sehingga menimbulkan gejala-gejala menopause (Ambler, Bieber dan Diamond, 2012).

Penurunan libido pada perempuan menopause selain akibat penurunan estrogen juga disebabkan oleh berkurangnya hormon testosteron. Pada perempuan lansia, kadar testosteron bebas berkurang, mengakibatkan hilangnya hasrat dan kenikmatan seksual, berkurangnya perasaan sejahtera, dan perasan lelah yang menetap (Trudel, Turgeon dan Piché, 2010; Ambler, Bieber dan Diamond, 2012).

Pada pria terjadi penurunan kadar testosteron sehingga menimbulkan sindroma Low Testosterone, dengan gejala perubahan mood, berkurangnya energi, lemah, berkeringat, berkurangnya dorongan seksual dan disfungsi ereksi (Montorsi et al., 2003).

\section{Penyakit}

Penyakit-penyakit kronis seperti penyakit kardiovaskular, diabetes, artritis dan kanker, memberikan dampak negatif terhadap respon dan fungsi seksual. Penyakit-penyakit tersebut menganggu fungsi seksual secara langsung melalui mekanisme fisiologis mempengaruhi endokrin, saraf dan pembuluh darah yang berperan dalam responseksual serta organ reproduksi dan juga secara tidak langsung dengan membatasi fungsi tubuh (Trudel, Turgeon dan Piché, 2010; Lochlainn dan Kenny, 2013).

\section{Obat-obatan}

Obat-obatan yang dapat mengganggu fungsi seksual sebaiknya diberikan dalam waktu yang terbatas. Jika dibutuhkan pengobatan dalam jangka waktu yang lama sangat diperlukan untuk memberikan terapi terhadap keluhan disfungsi seksual yang dialami pasien. Obat-obatan yang terkait dengan disfungsi seksual seperti golongan antihipertensi, antipsikotik, antidepresan, alphablockers, antikolinergik dan narkotika (Gareri et al., 2014; Hockenberry dan Masson, 2015).

\section{Faktor Psikologis}

Seksualitas pada laki-laki dan perempuan dibentuk oleh sosial dan budaya. Budaya menetapkan harapan-harapan, keyakinan dan perilaku terhadap seksualitas. Pandangan sosial ini mengakibatkan lansia menarik diri dari segala bentuk ekpresi seksual, dan mengabaikan atau menekan hasrat seksual karena hal tersebut dianggap "sakit", "tidak pantas", atau "salah" (Phanjoo, 2000; Delamater dan Sill, 2016).

Riwayat trauma seksual memberikan dampak negatif terhadap kehidupan seksual, kepuasan serta fungsi seksual pada laki-laki dan perempuan. Pasien dengan riwayat trauma akan terjadi 
kesulitan dalam merasakan intimasi. Padahal kemampuan untuk merasakan intimasi dalam aktivitas seksual dibutuhkan untuk membentuk hubungan yang romantis (Zoldbrod, 2015; Franckowiak, 2017).

Hal lain yang mempengaruhi hasrat serta aktivitas seksual perempuan adalah adanya Pronatalisme, yaitu tekanan sosial untuk bereproduksi dan menonjolkan reproduksi sebagai tujuan utama dari aktivitas seksual. Hilangnya kemampuan reproduksi pada perempuan yang menopause memunculkan keyakinan bahwa sudah tidak ada lagi alasan baginya melakukan aktivitas seksual (Delamater, 2012).

\section{Keharmonisan Rumah Tangga pada Lansia}

Pernikahan merupakan fenomena sosial dimana dua orang hidup bersama, saling bergantung satu sama lain untuk mengembangkan kepribadian, kemampuan serta kecakapan. Setiap pasangan menginginkan pernikahan yang harmonis, untuk mencapai rumah tangga yang harmonis diperlukan adanya kepuasan dalam pernikahan. Komunikasi yang efektif, derajat intimasi dan seksualitas merupakan faktor penentu tercapainya kepuasan pernikahan pada pasangan lansia (Melton, Hersen dan Hasselt, 1995; Khazaei, Rostami dan Zaryab, 2011).

\section{Kepuasan Pernikahan}

Kepuasaan pernikahan adalah derajat kepuasan dan ketidakpuasan relatif yang dirasakan pasangan dalam suatu hubungan. Kepuasan pernikahan dipengaruhi oleh banyak hal, diantaranya komunikasi, afeksi dan cinta. Kriteria kepuasan pernikahan bervariasi, tergantung pada norma-norma budaya, kewajiban-kewajiban serta nilai-nilai yang dianut oleh seseorang (Volsky, 1998; Ziaee et al., 2014).

Salah satu faktor yang juga sangat penting dalam menentukan kepuasaan pernikahan adalah kemampuan pasangan tersebut untuk menyelesaikan konflik. Pasangan lansia, mampu mengelola konflik yang mereka hadapi dengan cara yang lebih positif dari pada pasangan yang lebih muda. Hal ini bisa terjadi karena pada pernikahan jangka panjang intimasi dan kualitas komunikasi pasangan sudah lebih baik (Levenson, Carstensen dan Gottman, 1993).

\section{Intimasi}

Interaksi intimasi membentuk dasar intimasi dalam sebuah hubungan. Interaksi intimasi merupakan interaksi antara pasangan berupa saling berbagi masalah-masalah yang sifatnya pribadi, merasa nyaman dengan diri sendiri dan pasangan, dan saling memahami satu sama lain (Volsky, 1998).

Lansia yang bahagia, sehat, merasa puas dengan hidupnya dan mandiri biasanya memiliki hubungan yang dekat dengan pasangannya, saling mendukung satu sama lain dan dyadic intimasi (Volsky, 1998).

Beberapa perilaku intimasi, seperti bersentuhan, dan hubungan seksual, akan berkurang seiring berjalannya pernikahan, tetapi pengalaman intimasi (seperti, perasaan dicintai dan kebersamaan) tidak berkurang pada hubungan jangka panjang. Bahkan cinta dan kebersamaan akan semakin hidup pada saat mencapai usia lanjut (Volsky, 1998). 
Jika intimasi terbentuk dengan baik, pasangan bisa saling mengerti perubahan kondisi yang mereka alami terkait usia. Mereka memahami jika terjadi penurunan aktivitas seksual dikarena proses penuaan yang terjadi pada diri mereka sehingga mereka memperluas makna dari seksualitas. Bagi mereka hubungan seksual tidak hanya terbatas di kamar tidur saja tetapi hubungan ini diperluas menjadi hubungan di luar kamar tidur (Volsky, 1998; Hinchliff dan Gott, 2004).

\section{Komunikasi Pasangan}

Komunikasi yang baik mempengaruhi kepuasaan seksual yang akhirnya akan berdampak pada kepuasan pernikahan. Kehidupan seksual pasangan akan menjadi lebih baik jika komunikasi diantaranya keduanya bagus. Pasangan yang kurang mampu mengatur emosi dan kurang mampu berkomunikasi dengan efektif cenderung menjadi defensive dan menarik diri dari konflik, perilaku seperti ini akan menyebabkan timbulnya ketidakpuasaan pernikahan dan bahkan bisa berakibat perceraian (Litzinger dan Gordon, 2007).

Tetapi komunikasi bukan merupakan satu-satunya penentu kepuasan pernikahan, kepuasan seksual juga memberikan kontribusi yang penting dalam menentukan kepuasan pernikahan (Litzinger dan Gordon, 2007).

\section{Kepuasan Seksual}

Kepuasan seksual adalah respon efektif yang timbul dari evaluasi subyektif seseorang terhadap dimensi positif atau negatif terkait hubungan seksual yang dialami seseorang. Kepuasan seksual dipengaruhi oleh berbagai faktor, diantaranya usia pernikahan, usia, perbedaan usia pasangan, tingkat pendidikan dan jumlah anak (Young et al., 1998; Yeh et al., 2006; Ziaee et al., 2014).

Aktivitas seksual pada lansia tidak hanya sebagai penegasan daya tarik, tetapi juga untuk identitas diri, merasa diinginkan dan dihargai. Seiring bertambahnya usia terjadi penurunan aktivitas seksual, tetapi hal ini tidak mempengaruhi kepuasan seksual. Mereka beradaptasi dengan kondisi yang dialami dan mencari alternatif lain dalam melakukan hubungan aktivitas seksual seperti saling membelai dan bermanja-manja. Aktivitas seksual juga dpat memperkuat ikatan pernikahan (Hillman, 2000; Hinchliff dan Gott, 2004; McCarthy dan McCarthy, 2004).

Selain faktor-faktor yang telah disebutkan di atas, perjalanan kehidupan pernikahan juga dipengaruhi oleh adanya kelekatan yang aman. Kelekatan yang aman akan mempengaruhi kenyamanan individu dan kestabilannya serta kualitas hubungan pernikahan (Hirschberger et al., 2009).

Diperlukan adanya kepaduan antara semua komponen yang telah dijelaskan sebelumnya. Walaupun masih banyak hal-hal lain yang mempengaruhi kulitas pernikahan tetapi hal-hal tersebut di atas dianggap yang memberiksan kontribusi penting. Setelah kepuasaan pernikahan timbul, rumah tangga akan berjalan dengan harmonis dan menyenangkan. 


\section{Disfungsi Seksual dan Pengaruhnya terhadap Keharmonisan Rumah Tangga pada Lansia}

Disfungsi seksual pada lansia tidak terlalu mempengaruhi kualitas pernikahan. Hal ini disebabkan karena usia pernikahan yang sudah lama sehingga pasangan sudah saling mengerti satu sama lain dan sudah beradaptasi jika terjadi perubahan dalam hubungan seksual dan pernikahannya. Komunikasi diantara keduanya juga berjalan dengan baik. Mereka percaya terhadap pasangan sehingga bisa dengan nyaman menyampaikan yang mereka inginkan sampai pada masalah seksual yang paling pribadi (Litzinger dan Gordon, 2007; Murphy, Hudson dan Cheung, 2015; Jafarbegloo, Bakouei dan Dadkhahtehrani, 2017).

Perubahan yang paling sering dijumpai dalam hubungan seksual pada pernikahan lansia adalah berkurangnya penetrative sex. Hal ini bisa diakibatkan oleh disfungsi seksual ataupun kondisi kesehatan fisik lainnya, baik diri sendiri maupun pasangan. Senggama bukan lagi satu-satunya aktivitas seksual, pasangan masih bisa terlibat secara seksual tanpa melakukan senggama. Mereka beradaptasi terhadap kondisi ini dengan cara melakukan kontak fisik yang lebih umum, seperti bersentuhan, berpelukan dan saling membelai. Perubahan ekspresi seksual ini tidak mempengaruhi hubungan pernikahan mereka. Mereka tetap merasa bahagia dan puas hanya dengan berpelukan dan berpegangan walaupun tidak melakukan penetrative sex (Hinchliff dan Gott, 2004).

Pada kasus lansia yang masih aktif secara seksual tetapi terhambat karena kondisi medis, misalnya penyakit jantung, mereka beradaptasi dengan cara melakukan hubungan seksual secara perlahan atau mencari hari dimana kondisi kesehatan pasangan lebih baik.

Hambatan dalam melakukan hubungan seksual hanya memberikan sedikit dampak dan para lansia bisa beradaptasi dengan kondisi tersebut. Mereka merubah persepsi dan memperluas arti dari aktivitas seksual. Berpelukan juga termasuk aktivitas seksual, senggama tidak terlalu penting saat usia sudah bertambah dan sudah tidak mampu lagi, tetapi hasrat untuk mencintai pasangan yang terpenting. Cinta adalah ketika melakukan hal-hal yang disenangi bersama-sama (Gott dan Hinchliff, 2003; Hinchliff dan Gott, 2004).

Deskripsi tersebut menunjukkan rasa kebersamaan, kenikmatan dan mereka tetap bisa merasakan intimasi dalam hubungan mereka walaupun tanpa melakukan penetrative sex. Pembentukan intimate relationship, memerlukan komunikasi yang baik dan efektif. Komunikasi merupakan bahan baku yang penting dalam pernikahan lansia. Komunikasi di dalam pernikahan dan kepuasan seksual juga berpengaruh dalam menentukan kepuasaan pernikahan. Saat pasangan belajar untuk berkomunikasi dengan baik maka kehidupan seksual mereka akan meningkat. Hal ini menunjukkan bahwa hambatan-hambatan tersebut tidak memberikan dampak negatif terhadap pernikahan (Hinchliff dan Gott, 2004; Litzinger dan Gordon, 2007). 


\section{Penatalaksanaan}

Penatalaksanaan yang holistik sangat diperlukan untuk menangani disfungsi seksual karena seksualitas dipengaruhi oleh banyak faktor mulai dari faktor biologis, psikologis dan budaya. Tatalaksana yag dapat diberikan bisa berupa konseling dan edukasi tentang seksual serta perubahan-perubahan yang terjadi seiring bertambah usia, terapi hormon, terapi farmakologi, terapi perilaku, terapi pasangan, hipnoterapi, mindfulness, conjugal enrichment program, terapi okupasi bahkan dapat dilakukan pembedahan.

Harus dipahami juga bahwa disfungsi seksual merupakan masalah pasangan, memahami hal ini sebagai masalah bersama akan meningkatkan upaya penyelesaian masalah. Pria yang selalu mengalami ejakulasi dini atau perempuan yang tidak pernah merasakan orgasme cenderung akan berubah perilakunya jika hal ini ditangani sebagai masalah pasangan. Tugas tiap-tiap pasangan untuk mengembangkan gaya seksual yang nyaman bagi keduanya. Tantangan ini akan meningkatkan intimasi karena jika pasangan berhasil mengahadapinya bersama maka mereka menjadi semakin mengenal diri mereka satu sama lain dan juga masalah seksualitas mereka.

\section{Kesimpulan}

Seksualitas merupakan bagian dari kedekatan fisik dan emosional yang ingin terus dirasakan oleh seseorang baik laki-laki ataupun perempuan walaupun usia sudah bertambah. Masalah terkait seksualitas yang banyak dijumpai seiring bertambahnya usia adalah terjadinya disfungsi seksual. Disfungsi seksual pada lansia bisa diakibatkan oleh interaksi dari faktor biologi, psikologis, sosial dan kebudayaan. Seksualitas juga merupakan salah satu komponen yang penting di dalam kehidupan manusia termasuk kehidupan rumah tangga. Rumah tangga yang harmonis didapat apabila tercapainya kepuasan dalam pernikahan. Banyak faktor yang dapat mempengaruhi kepuasaan pernikahan diantaranya yang terpenting adalah intimasi, seksualitas dan komunikasi. Riwayat kelekatan yang aman juga mempengaruhi kemampuan seseorang dalam merasakan intimasi sehingga secara tidak langsung bisa mempengaruhi kepuasannya terhadap pernikahan.

Pada rumah tangga lansia terjadinya disfungsi seksual tidak terlalu mempengaruhi hubungan rumah tangga mereka. Para lansia yang memahami mengenai perubahan yang terjadi seiring bertambahnya usia biasanya akan segera beradaptasi dengan kondisinya. Pada lansia hubungan seksual (intercourse) bukan merupakan hal yang utama, mereka sudah cukup puas dengan hanya berpelukan, saling membelai atau bermanja-manja saja. Aktivitas seksual mereka ini justru semakin menambah keintiman diantara mereka. Penanganan yang holistik sangat diperlukan untuk mengatasi disfungsi seksual karena seksualitas dipengaruhi oleh banyak faktor mulai dari faktor biologis, psikologis dan budaya. 


\section{Daftar Pustaka}

1. Ambler, D. R., Bieber, E. J. and Diamond, M. P. (2012) 'Sexual Function in Elderly Women: A Review of Current Literature', 5(1), pp. 16-27. doi: 10.3909/riog0156.

2. Danesh, H. B. and Nasseri, A. (2017) The Unity-Based Family: An Empirical Study of Healthy Marriage, Family, and Parenting. 1st edn. Cambrige Scholars Publishing.

3. Delamater, J. (2012) 'Sexual Expression in Later Life: A Review and Synthesis Sexual',The Journal of Sexual Research, 49(2012), pp. 125-141. doi: 10.1080/00224499.2011.603168.

4. Delamater, J. D. and Sill, M. (2016) 'Sexual desire in later life',The Journal of Sexual Research, (December). doi: 10.1080/00224490509552267.

5. Franckowiak, M. (2017) Intimacy after Sexual Trauma: Clinical Perspectives. St. Catherine University.

6. Gareri, P. et al. (2014) 'Erectile Dysfunction in the Elderly: An Old Widespread Issue with Novel Treatment Perspectives', International Journal of Endocrinology, 2014.

7. Gott, M. and Hinchliff, S. (2003) 'How important is sex in later life? The views of older people', Social Science \& Medicine, 56, pp. 1617-1628.

8. Hillman, J. L. (2000) Clinical Perspectives on Elderly Sexuality Issues in the Practice of Psychology. 1st edn. New York: Springer Science + Business Media New York.

9. Hinchliff, S. and Gott, M. (2004) 'Intimacy, commitment, and adaptation: Sexual relationships within long-term marriages', Journal of Social and Personal Relationship, 21(5), pp. 595-609. doi: 10.1177/0265407504045889.

10. Hirschberger, G. et al. (2009) 'Attachment, Marital Satisfaction, and Divorce During the First Fifteen Years of Parenthood', National Institutes of Mental Health, 16(3), pp. 401-420. doi: 10.1111/j.1475-6811.2009.01230.x.Attachment.

11. Hockenberry, M. S. and Masson, P. (2015) 'Erectile Dysfunction in the Elderly', Curr Geri Rep, pp. 33-43. doi: 10.1007/s13670-014-0107-4.

12. Jafarbegloo, E., Bakouei, S. and Dadkhahtehrani, T. (2017) 'Marital Satisfaction in Menopausal Women with and without Sexual Dysfunction', Journal of Midwifery \& Reproductive Health, 5(4), pp. 1053-1058. doi: 10.22038/jmrh.2017.8898.

13. Khazaei, M., Rostami, R. and Zaryab, A. (2011) 'The Relationship between sexual dysfunctions and marital satisfaction in Iranian married students', Social and Behavioral Sciences, 0, pp. 783-785. doi: 10.1016/j.sbspro.2011.10.152.

14. Levenson, R. W., Carstensen, L. L. and Gottman, J. M. (1993) 'Long-Term Marriage : Age, Gender, and Satisfaction', American Psychological Association, 8(2), pp. 301-313.

15. Lindau, S. T. et al. (2007) 'A Study of Sexuality and Health among Older Adults in the United States', The New England Journal of Medicine.

16. Litzinger, S. and Gordon, K. C. (2007) 'Exploring Relationships Among Communication, Sexual Satisfaction, and Marital Satisfaction', Journal of Sex and Marital Therapy, 31(July 
2013), pp. 37-41. doi: 10.1080/00926230591006719.

17. Lochlainn, M. N. and Kenny, R. A. (2013) 'Sexual Activity and Aging', Journal of the American Medical Directors Association. Elsevier Ltd, 14(8), pp. 565-572. doi: 10.1016/j.jamda.2013.01.022.

18. McCarthy, B. and McCarthy, E. (2004) Getting it Right the First Time. 1st edn. New York: Brunner-Routledge.

19. Mcnicoll, L. (2008) 'Sexuality In the Elderly', Geriatric for the Practicing Physician, 91, pp. $321-322$.

20. Melton, A., Hersen, M. and Hasselt, V. B. Van (1995) 'Parameters of Marriage in Older Adults : A Review of The Literature', Clinical Psychology Review, 15(8), pp. 891-904.

21. Montorsi, F. et al. (2003) 'The ageing male and erectile dysfunction', BJU Interenational, 92, pp. 516-520. doi: 10.1046/j.1464-410X.2003.04378.x.

22. Murphy, G. J., Hudson, W. W. and Cheung, P. P. L. (2015) 'Marital and sexual discord among older couples', Nationnal association of Social Workers, pp. 11-16.

23. Phanjoo, A. L. (2000) 'Sexual dysfunction in old age', Advances in Psychiatric Treatment, 6, pp. 270-277.

24. Sadock, B. J., Sadock, V. A. and Ruiz, P. (2017) Kaplan \& Sadock's Comprehensive Textbook of Psychiatry. 10th edn. China: Wollters Kluwer.

25. Trudel, G., Turgeon, L. and Piché, L. (2010) 'Marital and sexual aspects of old age', Sexual and Relationship Therapy, (November 2014), pp. 37-41. doi: 10.1080/713697433.

26. Volsky, J. A. (1998) Intimacy, Marital Satisfaction, and Sexual ity in Mature Couples. Concordia University, Canada.

27. Yeh, H. et al. (2006) 'Relationships Among Sexual Satisfactin, Marital Quality, and Marital Instability at Midlife', Journal of Family Psychology, 20(2), pp. 339-343. doi: 10.1037/0893-3200.20.2.339.

28. Young, M. et al. (1998) 'Correlates of sexual satisfaction in marriage', The Canadian Journal of Human Sexuality, 7, pp. 115-127.

29. Ziaee, T. et al. (2014) 'The Relationship between Marital and Sexual Satisfaction among Married Women Employees at Golestan University of Medical Sciences, Iran', Ira, 8(4), pp. $44-51$.

30. Zoldbrod, A. P. (2015) 'Sexual Issues in Treating Trauma Survivors', Curr Sex Health, 7, pp. 3-11. doi: 10.1007/s11930-014-0034-6. 